\title{
PREPARATION OF READY-TO-SERVE BEVERAGE FROM TROPICAL AL- MOND (TERMINALIA CATTAPPA) FRUIT PULP
}

\author{
Weerasekara WMRAB ${ }^{1}$, Rathnayaka RMUSK*1 and Saranandha $\mathrm{KH}^{2}$ \\ ${ }^{1}$ Department of Food Science \& Technology, Faculty of Applied Science, Sabaragamuwa University of Sri \\ Lanka, Belihuloya, Sri Lanka \\ ${ }^{2}$ Food Research Unit, Department of Agriculture, Peradeniya, Sri Lanka
}

Accepted: $1^{\text {st }}$ August, 2012

Abstract

Tropical Almond (Kottamba) is a locally available underutilized fruits which is rich in vitamins, pigments and antioxidants. In this research, ready to serve drink (RTS) was produced using ripened Tropical Almond fruits. $\mathrm{P}^{\mathrm{H}}$, titrable acidity and Brix value of the ripen Tropical Almond fruits were determined using standard methods. Four RTS samples were prepared according to SLS standards with different Brix value as $6^{0}, 9^{0}, 12^{0}$ and $15^{\circ}$. Sensory evaluation, microbial analysis, $\mathrm{P}^{\mathrm{H}}$ and titrable acidity measurements were done for fresh products as well as for products stored at ambient temperature for six months. Sensory evaluation was conducted by trained sensory panel subjectively using 7 point hedonic scale. Results were analyzed according to Friedman test at $95 \%$ level of significant. Proximate analysis was carried out for the best sample which was identified by the above tests. The selected best sample (Brix valve $\mathbf{1 2}^{\circ}$ ) gave acceptable results according to SLS standers in all tests performed. In the proximate analysis, protein content and fiber content, for the best product, were found to be $0.043 \%$ and $0.82 \%$ respectively. There was no microbial colony formation observe even after six month of storage. Considering the results it was concluded that Tropical Almond fruit pulp can be used to produce RTS with acceptable qualities according to the SLS standards.

Key words: Tropical Almond, Physico-chemical analysis, Ready to serve beverage, Sensory evaluation.

\section{INTRODUCTION}

Tropical Almond (Terminaliya catappa: Combretaceae) is primarily a costal tree. In Sri Lanka it is grown in the lowland areas in various parts of the island up to an elevation of about $300 \mathrm{~m}$ as a beatification and fruit plant (Gunasena et al. 2007). Tropical Almond fruit is known to contain antioxidant, anticancer and anti-diabetic compounds and hence it is an important medicinal plant (Lall and Singh 1999 Nagappa et al. 2003). However, most; of the Tropical almond fruits are wasted during the fruiting season as they have not been utilized to produce processed products. Production of Ready to Serve (RTS) beverages from fruit pulps of some underutilized fruit plants has helped to reduce these fruits being wasted during the fruiting season (Nilugin et al. 2010, Abeywickrama etal. 2010, Priyanthi et al. 2008, Arachchi etal. 2003). Therefore, an effort was made to develop RTS health drink with

*Corresponding author: udayar@sab.ac.lk acceptable quality parameters from Tropical Almond.

\section{MATERIALS AND METHODS}

Ripen fruits with pink to purple colour were harvested from well grown tree at Alawwa. Fruits were transported to the laboratory using plastic crates for preparation of RTS. Four different RTS samples were prepared by the following procedure. Fruit flesh (150g) was blended well and pulp was separated using a sieve. Then $1000 \mathrm{ml}$ of water was added into pulp and mixed well. While mixture was heated, $6 \mathrm{~g}$ of citric acid and different amounts of sugar were added to obtain different Brix values $(120 \mathrm{~g}, 160 \mathrm{~g}, 220 \mathrm{~g}$, and $360 \mathrm{~g}$ to obtain 6 ${ }^{\circ}, 9^{\circ}, 12^{\circ}$ and $15^{\circ}$ Brix solutions respectively) and mixed well. Then the mixture was kept for $20 \mathrm{~min}$ at $80^{\circ} \mathrm{C}, 0.3 \mathrm{~g}$ of Sodium-metabisulphite was added and mixed well. Then, prepared RTS drinks were filled into bottles and sealed. $\mathrm{P}^{\mathrm{H}}$ of the prepared RTS was recorded using a 


\section{WEERASEKERA ET AL: READY-TO-SERVE BEVERAGE FROM TROPICAL ALMOND}

$\mathrm{P}^{\mathrm{H}}$ meter. Brix value of RTS was recorded using a refrectometer. Ten milliliter of RTS was titrated against $0.1 \mathrm{ml}$ of $\mathrm{NaOH}$ to determine the titrable acidity of the product.

Microbial analysis was done by Total plate count method. Each prepared drink was used to prepare dilutions of $10^{0}, 10^{-1}$ and $10^{-2}$ and microbial counts were taken in three replicates. Microbial counts were taken 6 month after storage at ambient temperature.

Sensory evaluation was conducted for the Colour, Odour, Appearance, Flavor, Sweetness, Bitterness and Overall acceptability, by 15 trained panelists subjectively using 7 point hedonic scale. Four samples were coded giving three-digit number for each sample. Coded samples, ballot papers, pens and water were given for each panelists and suitable environment was provided for them for their evaluation. Results of the sensory evaluation were analyzed using computer aided MINITAB 14 statistical analysis package according to Friedman test at 95\% significant level. Sensory evaluation was also conducted just after preparation and after six month storage at ambient temperature.

Protein percentage of the selected best Tropical Almond RTS was estimated by kjeldhal method (Otles, 2005) in three replicates. Fiber content of the selected best product was determined according to the method of AOAC (1984) with three replicates.

\section{RESULTS AND DISCUSSION}

According to SLS standards $\mathrm{P}^{\mathrm{H}}$ value should be lower than 4 in RTS drink which is suitable to overcome microbial growth. Average $\mathrm{P}^{\mathrm{H}}$ value of Tropical almond fruit was 3.2 and hence there is a potential to produce RTS drink form this fruit. In normal conditions, Brix value of RTS is maintained 10 to 15 . Average Brix value of raw tropical almond fruit was 7 . Brix value can be increased by adding sugar to reach the required limit in RTS preparation. How- ever, due to this low Brix value Tropical Almond is not suitable to produce other products such as jam, cordial etc. Titrable acidity of Tropical Almond raw fruits was $0.846 \%$. This high Titrable acidity is important to maintain natural flavor of the frit as well as to control microbial growth.

Brix, pH and Acidity are three parameters extremely important as they decide the quality of RTS beverages (Patil et. al. 2009). As shown in the table 1 , no significant changes in $\mathrm{P}^{\mathrm{H}}$ value, Titrable acidity value and $\mathrm{Brix}^{\circ}$ were observed during the storage period of six month. These tested values were in the SLS recommended ranges for the RTS throughout the storage period. Hence, Tropical Almond can be used to prepare RTS in recommended standards.

Table 1: Mean values of $\mathbf{P}^{\mathrm{H}}$, Titrable acidity and Brix of prepared ready to serve drinks

\begin{tabular}{lllllll}
\hline Sample & Parameter & \multicolumn{4}{c}{ Prepared RTS with different Brix values } \\
\hline & & $6^{\circ}$ Brix & $9^{\circ}$ & Brix & $12^{\circ}$ Brix & $15^{\circ}$ Brix \\
\hline \multirow{4}{*}{ Initial } & PH & $3.8^{\text {a }}$ & $3.7^{\text {a }}$ & $3.8^{\mathrm{a}}$ & $3.8^{\mathrm{a}}$ \\
& TA & $0.58^{\mathrm{a}}$ & $0.59^{\mathrm{a}}$ & $0.57^{\mathrm{a}}$ & $0.59^{\mathrm{a}}$ \\
6 & Brix $^{\circ}$ & $6^{\mathrm{a}}$ & $9^{\mathrm{b}}$ & $12^{\mathrm{c}}$ & $15^{\mathrm{d}}$ \\
Months & PH & $3.7^{\mathrm{a}}$ & $3.7^{\mathrm{a}}$ & $3.7^{\mathrm{a}}$ & $3.7^{\mathrm{a}}$ \\
& TA & $0.61^{\mathrm{a}}$ & $0.62^{\mathrm{a}}$ & $0.61^{\mathrm{a}}$ & $0.61^{\mathrm{a}}$ \\
& Brix $^{\circ}$ & $6^{\mathrm{a}}$ & $8^{\mathrm{b}}$ & $11^{\mathrm{c}}$ & $15^{\mathrm{d}}$ \\
\hline
\end{tabular}

Treatment means in a row having common letter(s) are not significantly different by DMRT $5 \%$

No microbial growth observed throughout the storage period. Low microbial level of initial samples, weakening of bacterial growth by lower $\mathrm{P}^{\mathrm{H}}$ due to added Citric acid, bacterial death due to high temperature used in processing, and effect of malic acid present in the fruit could be the reasons for this low growth of microorganisms in prepared RTS.

Sensory evaluations were performed at initial stage and six month after storage. Mean values of the obtained sensory data is shown in the table 2. Samples with $12^{\circ}$ Brix and $15^{\circ}$ Brix were identified as best for different attributes at sensory tests performed at different time intervals. However, $12^{\circ}$ Brix sample was 
identified as the best sample in most of those tests for most of the attributes and hence was selected to perform proximate analysis. According to the results of proximate analysis, protein content and fiber content of $12^{\circ}$ Brix sample was $0.043 \%$ and $0.82 \%$ respectively. The fiber content of this product is higher than other RTS drinks available in the market and it would be an additional benefit of the product.

\section{CONCLUSION}

Ready to Serve (RTS) Tropical Almond beverage prepared with $12^{\circ}$ Brix was detected to possess the best physicochemical, microbial and organoleptical properties. All tested parameters for the selected RTS product was in accordance with the commercial recommendation for the RTS beverages by the Sri Lanka Standard Institute. There was no microbial colony formation observed even after six months of storage and therefore it is safe for human consumption. The selected Tropical almond RTS could be stored at ambient temperature for a period of six months without any significant quality change. Hence, this formulation is considered as a best solution to overcome the wastage of fruits during the fruiting season.

\section{REFERENCES}

Abeywickrama WSS and Jayasooriya MCN 2010 Formulation and quality evaluation of cordial based on Kirala (Sonneratia caseolaris) fruit pulp. Tropical agricultural research and extension, 13 (1), 16-18.

AOAC 1984. Official Methods of Analysis. $14^{\text {th }}$ Edn., Association of Official Analytical Chemist, Washington DC., pp: 602-612.

Arachchi MALNM 2003 Preparation of ready to serve fruit drink using raw mango. M.Sc. Thesis. University of Peradeniya, Sri Lanka. pp. 24-26.

Gunasena HPM, Puspakumara DKNG, Singth VP 2007 Under utilized fruit trees in Sri Lanka. Volume 1, pp 437-451.

Lall SB and Singh B 2001 Role of nutrition in toxic injury, Indian journal of Experimental Biology, 1999 Feb: 37(2): 109-16.

Nagappa AN, Thakurdesai PA, Venkat RN, Singh J 2003, Antidiabetic activity of Terminalia catappa Linn fruits, Journal of Ethnopharmacology: 8845 -50 .

Nelugin SE and Mahendran T 2010 Preparation of ready to serve (RTS) beverage from Palmyrah (Borassus flabellifer L.) fruit pulp. Journal of Agricultural Sciences, vol.5, no2, 80-88.

Otles S 2005 Methods of analysis of food components and additives, Tayler and Francis Group.

Patil AMS and Kattimani KNS 2009 Variability studies in physicochemical parameters in Kokum (Garcinia indica Choicy) for syrup preparation. Karnataka journal of agricultural science, 22(1), 244-245.

Priyanthi HGS 2008 Development of a ready-to-serve (RTS) drink using Veralu/Ceylon Olive (Elaeocarpus serratus). M.Sc. Thesis. Rajarata Universuty, Sri Lanka. pp. 35-56.

Table 2 : Mean values of data obtained from sensory tests

\begin{tabular}{lcccccccc}
\hline Testing time & Sample & Colour & Odor & Appearance & Flavor & Sweetness & Bitterness & $\begin{array}{c}\text { overall } \\
\text { acceptability }\end{array}$ \\
\hline \multirow{2}{*}{ Initial } & 6 & 5.34 & 5.75 & 5.25 & 4.03 & 4.44 & 6.50 & 5.00 \\
& 9 & 5.71 & 5.75 & 5.50 & 4.90 & 4.56 & 5.00 & 4.75 \\
& 12 & 5.71 & 5.75 & 5.75 & 6.03 & 6.18 & 6.00 & 5.87 \\
\multirow{2}{*}{ Sig. level } & 15 & 6.59 & 5.75 & 6.50 & 6.10 & 6.06 & 6.00 & 6.37 \\
& & $\mathrm{NS}$ & $\mathrm{NS}$ & 0.0 & 0.0 & 0.0 & 0.0 & 0.0 \\
\multirow{3}{*}{ 6 months } & 6 & 6.05 & 5.22 & 5.00 & 5.10 & 4.32 & 5.00 & 5.00 \\
& 9 & 5.73 & 5.30 & 5.00 & 5.00 & 5.25 & 5.00 & 5.02 \\
& 12 & 6.13 & 6.80 & 6.59 & 6.25 & 6.45 & 6.00 & 6.32 \\
\multirow{2}{*}{ Significance } & 15 & 6.17 & 6.35 & 6.48 & 6.10 & 6.25 & 6.00 & 6.26 \\
\hline
\end{tabular}

